\title{
BUILDING CUSTOMER LOYALTY ON CUSTOMER BANKING
}

\author{
Linda Sariningrum ${ }^{1^{*}}$, Moch. Zulfa ${ }^{2^{*}}$
}

\begin{abstract}
* Affiliation:
${ }^{1,2}$ Master of Management Program, Sultan Agung Islamic University
\end{abstract}

\begin{abstract}
:
The primary purpose of this research is to investigate and examine the effect of Shared Value Quality and Communication Quality on Customer Loyalty through Trust, and to propose an empirical model to investigate such relationships. A total of 100 customers of Syari'ah BNI Bank of Semarang completed questionnaires on Shared Value Quality, Communication Quality, Trust, and Customer Loyalty. Results from SmartPLS 3.0 based on structural equation modeling confirmed that Shared Value Quality and Communication Quality were positively related to Trust and Customer Loyalty; furthermore Trust was related to Customer Loyalty.

Keywords : Shared Value Quality, Communication Quality, Trust, Customer Loyalty
\end{abstract}

\section{INTRODUCTION}

Globalization and the growth of technological developments have spurred a new era of the emergence of e-commerce (Ibrahim et al., 2013). The term 'online banking' associated with internet banking or electronic banking has been defined appropriately as automated delivery of new and traditional banking products directly to customers through online and interactive communication channels (Mobarek, 2009). Online banking provides convenient facilities to financial institutions, customers, individuals and business entities in accessing their accounts and for engaging in business transactions and enabling account holders to obtain information about funding products as well as financing and other financial services through the network intranet and extranet (Singhal and Padhmanabhan, 2008).

Consumers can also conduct online banking transactions using ATM (Automatic Teller Machine), SMS banking (Short Mesagges System), Phone Banking, Internet banking and Mobile banking. Due to online banking facilities, customers can make many transactions such as customer service requests, transfer funds from one account to another, loan applications, open new accounts, and transactions between third party accounts. With rapid changes and advances in information technology (Talukder, 2014), online banking introduces new methods 
and systems for banking institutions providing their services to potential customers (Mobarek, 2009). By using the online facility, the customer can do many transactions such as balance inquiry, conduct account mutation check, print a bank statement, transfer funds between accounts in same bank, interbank, clearing, RTGS, check phone bill, electricity, credit purchase, online accounts, loan simulations, and so on.

Although e-banking services can improve bank efficiency and competitiveness, the implementation of e-banking in Syari'ah BNI Bank is not maximal yet because it raises the risk of higher cost implementation. Therefore, Syari'ah BNI Bank needs to know whether it is really ready to implement e-banking, and banks that want to offer services electronically must first ensure that all necessary infrastructure, labor and banking functions are available and work with efficiency. Thus, there is a need for Syari'ah BNI banks to assess their readiness to offer e-banking services to their customers thereby encouraging the emergence of customer loyalty.

\section{REVIEW OF LITERATURE Costomer Loyalty}

Bennet and Rundle-Thiele (2002) describe loyalty as a customer's intention to a company as a function of psychological processes. Shergill and Li (2005) define loyalty as the intention of consumers to re-use internet banking based on their experiences and expectations in the past. According to Dharmmesta (1999), the stages of loyalty are divided into 4, namely:

1. Cognitive loyalty, where consumers use information bases that forcefully refers to one brand over other brands. Its loyalty is based on consumer confidence in the information base reflected by brand quality. This first stage loyalty is not a form of strong loyalty.

2. Affective loyalty, namely consumer attitudes that are driven by satisfaction and consumer preferences. Loyalty stage is much more difficult to change because this loyalty has entered the minds of consumers as an attitude. This loyalty stage is reflected by the level of liking and level of customer satisfaction.

3. Conative loyalty, is loyal consumer conditions that are influenced by the intention to do something, which includes the intention or high commitment to make a purchase. Commitment at this stage has gone beyond affective loyalty. Intention to repurchase may be regarded as an early sign of loyalty.

4. Action loyalty is the stage where the connective aspect or intention to perform has been developed, i.e. converted into behavior or action.

If internet banking users trust internet banking services provided by a bank, the internet banking user has the intention to maintain their relationship with internet banking. The intention to maintain the relationship between internet banking users and internet banking provided by a bank is represented in the form of loyalty using the internet banking service. This is also supported by studies by Shergill and Li (2005); and Ribbink et. al.(2004).

\section{Trust}

Trust is a dynamic and multi-interpretative concept (Dimitriadis et al., 2011). In the context of syari'ah banking, trust is defined as the moral obligation of every individual in carrying out his duties in society. Islam places the highest emphasis on trust and regards it as 
a compulsory personality trait (Iqbal and Mirakhor, 2007). Therefore, the basic philosophy of the trust dimension in the syari'ah banking system can be seen as a symbol of trust, honesty, equality, equality between people, and the moral values set to enhance business relationships between banks and customers (Sauer, 2002).

Trust in the service industry is defined as the customer's belief that the service provider is capable of meeting the expected needs. Trust plays an important role in forming lasting customer relationships. Morgan and Hunt (1994) conceptualize that trust exists when one side has a belief in the reliability and integrity of the other partner. Customer trust plays an important role in the individual's intention to build a long-term relationship with a particular brand, service provider or product.

\section{SHARED VALUE QUALITY}

Shared values are values that convey the conception of the common good among people, expressed and disseminated through social interaction. The term shared value is closely related to the terms social values, socio-cultural values and plurality values that have been used to demonstrate concepts related to a sense of importance that transcend individual utility, and express multidimensionality values (Kenter et al., 2015).

According to the shared value paradigm, for value creation in inter-organizational systems, firms must have a re sponsib i lity to harmonize thei $r$ operations so as to promote economic prosp e rity and als o provid e value to the wider co m munity. By basing on this sustainable business, the search for short-term profits will be replaced by efforts to achieve long-term benefits for many people (Greenwood et al., 2011; Thornton et al., 2012).

Other research by Shergill and Li (2005); Mukherjee and Nath (2003) have proven that shared value affects trust. In brand communities and value creation practices, people develop close relationships and illustrate the fascinating values of their long-term social interactions, which make them trust and love the brand (Zhou et al., 2011). Previous research has shown that loyalty is increasing as consumers feel that organizations consider their feelings and values (Arnold et al., 2001; Landry et al., 2005; Rasheed and Abadi, 2014). Based on the review of literature and empirical evidence, the hypotheses proposed in this research are:

\section{H1: The higher the shared value quality is, the more customer loyalty increases}

\section{H2: The higher the shared value quality is, the more the trust increases}

In the literature reviewing the trust, researchers have stated that to create trust, business associations need to facilitate the achievement of perfect results by increasing the value of transactions and decreasing the cost of inter-organizational exchange transactions (Robson et al., 2008). Paparoidamis el al. (2017) proves that trust has a significant effect on customer loyalty. If a person trusts the other in an interpersonal relationship, he will depend on the other side and he will have a commitment in the relationship, where such a commitment will bring his intention to maintain the relationship (Darsono and Dharmmesta 2005). Based on this, the hypothesis proposed in this research is:

\section{H3: The higher the trust is, the more the customer loyality increases.}




\section{SHARED VALUE QUALITY}

According to Anderson and Narus (1990) cited by Maharsi (2006), communication can be defined as meaningful and timely sharing of information both officially and unofficially. Morgan and Hunt (1994) argue that past communications from others that are relevant, timely and reliable will increase trust. Trust is gained through openness in communications that specifically involve individual consumers and their relationships with banks (Mukherjee and Nath, 2003). According to Shergill and Li (2005), without using proper means of communicating, internet banking can not build a good relationship with its users.

Shergill and Li's research (2005); Mukherjee and Nath (2003); Morgan and Hunt (1994); Zehir et al. (2011) have proven that communication affects trust. Consistent brand communication has been found to play an important role in creating a positive brand attitude. The ability of brand names to evoke feelings like trust, confidence and the like suggests that brand names should not be ignored as a valid and useful way of communication in creating brand attitudes (Grace and O'Cass, 2005). Based on the review of literature and empirical research results from some previous researches, the empirical research model proposed in this study is as follows:

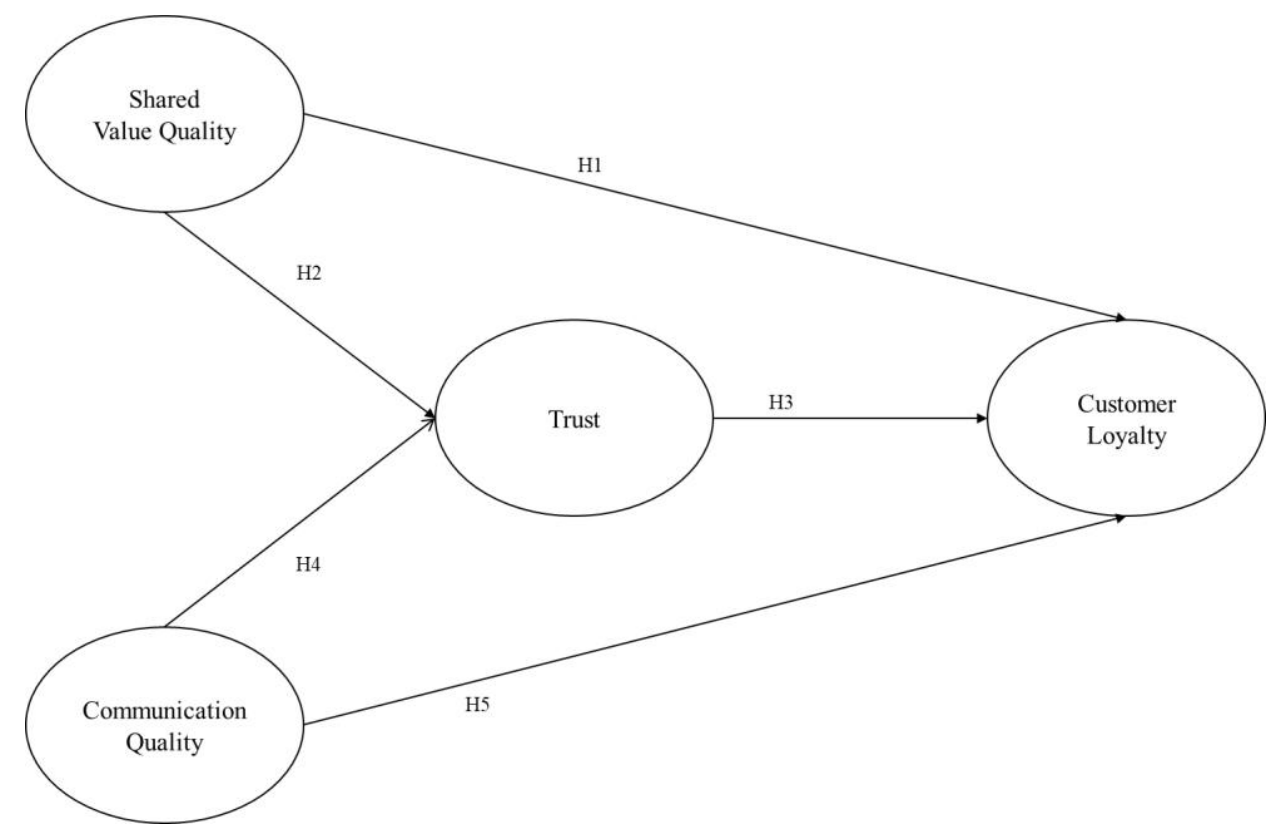

Figure 1. Empirical Research Model

\section{RESEARCH METHOD}

This study uses explanatory research and data collection technique used in this study is by using a questionnaire. The type of questionnaire is the closed one, where the answer has been predetermined and the respondent is not allowed to give another answer and then measured by using five likert scale. The sampling technique in this research uses purposive sampling so that 100 customers whose saving in Syari'ah BNI Bank, Branch of Semarang. 


\section{RESULT OF DATA ANALYSIS \\ Validity Test}

Validity test is used to measure the validity of a questionnaire. A questionnaire is said to be valid if it is able to uncover something that will be measured by the questionnaire (Ghozali, 2005). Validity test with SmartPLS 3 program is done by using convergent size and discriminant validity. Discriminant validity of the measurement model with reflective indicators is assessed based on outer loadings of measurements with constructs. The results of outer loadings of data processing using SmartPLS 3 are:

Table 1. Outer Loadings

\begin{tabular}{lllll}
\hline & Communication Quality & Customer Loyalty & Shared Value Quality & Trust \\
\hline X1.1 & & & 0,708907 & \\
X1.2 & & & 0,832233 & \\
X1.3 & & 0,766696 & \\
X2.1 & 0,791130 & & & \\
X2.2 & 0,829837 & & & \\
X2.3 & 0,830069 & & & 0,634225 \\
Y1.1 & & & 0,822508 \\
Y1.2 & & & 0,831762 \\
Y1.3 & 0,582431 & & \\
Y2.1 & 0,748461 & & \\
Y2.2 & 0,634403 & & \\
Y2.3 & & & \\
\hline
\end{tabular}

Source: primary analyzed data, 2017

From Table 1 it can be seen that the correlation of the construct of shared value quality, communication quality, trust, and customer loyalty with each indicator is higher above 0.5 , so the constructs in the estimated model meet the criteria of discriminant validity.

\section{Reliability Test}

The reliability test is performed by looking at the composite reability value of the indicator block which measures the construct. The result of composite reability will show satisfactory value if above 0.7 . Here is the composite reability value of the SmartPLS 3 output:

Table 2. Composite Reliability

\begin{tabular}{ll}
\hline & Composite Reliability \\
\hline Communication Quality & 0,857729 \\
Customer Loyalty & 0,694611 \\
Shared Value Quality & 0,814001 \\
Trust & 0,809884 \\
\hline Sounce Primary analyzed
\end{tabular}

Source: Primary analyzed data, 2017

Table 2 shows that the composite reability value for all constructs is above 0.7 indicating that all constructs in the estimated model meet the reliable ktiteria so that they can be used in the next research process. 


\section{Structural Model Testing (Inner Model)}

Inner model describes the relationship between latent variables based on the acquisition of output results from the model of load factor construction structure in the form of graph relationships between performance management variables, work attitude, and employee performance which can be seen in Figure 2 below:

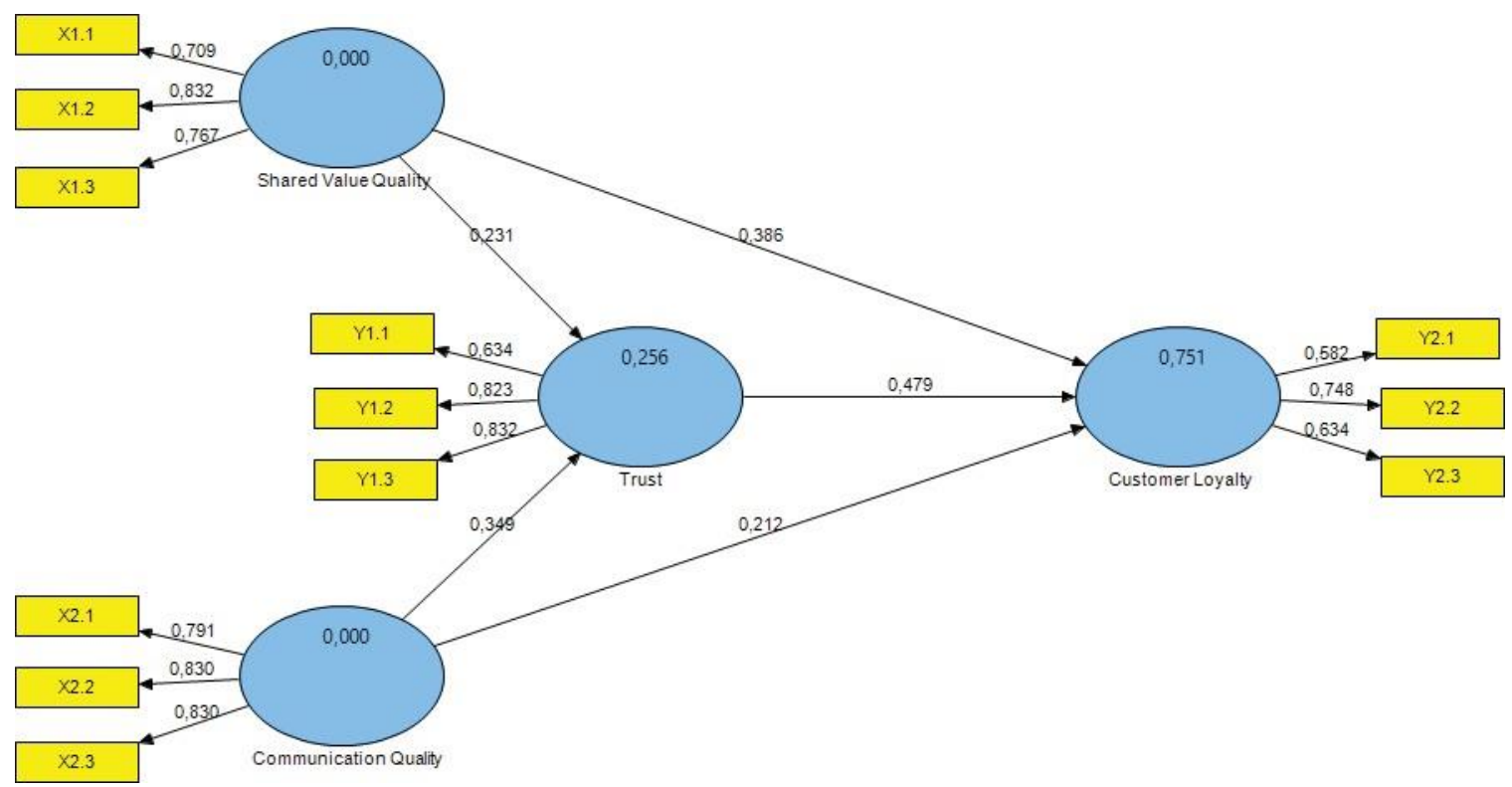

Figure 2. Structural Model before Moderation

Table 3. R-square

\begin{tabular}{lc}
\hline & R-square \\
\hline Shared Value Quality & \\
Communication Quality & \\
Trust & 0,256215 \\
Customer Loyalty & 0,750669 \\
\hline
\end{tabular}

Source: Primary analyzed data, 2017

Based on Table 3 shows, it shows that the R-square value of the trust construct is equal to 0.2562 which means that shared value quality and communication quality are able to explain the variance trust of $25.62 \%$ and the rest $(74.38 \%)$ influenced by other factors which are not examined in this research. Furthermore, the value of R-square is also found in the customer loyalty construct of 0.7507 which means that shared value quality, communication quality, and trust can explain the customer loyalty variance of $75.07 \%$ and the rest $(24.93 \%)$ influenced by other factors which are not examined in this research.

As for determining a hypothesis accepted or rejected, then the comparison between $\mathrm{t}$ statistic value and $\mathrm{t}$ table value with condition if $\mathrm{t}$ statistic $>\mathrm{t}$ table, hence hypothesis is accepted. For more details, it can be seen in Table 4 below: 
Table 4. Path Coefficients before Moderation

\begin{tabular}{lllllc}
\hline & $\begin{array}{l}\text { Original } \\
\text { Sample }\end{array}$ & $\begin{array}{l}\text { Sample } \\
\text { Mean }\end{array}$ & $\begin{array}{l}\text { Standard } \\
\text { Deviation }\end{array}$ & $\begin{array}{l}\text { Standard } \\
\text { Error }\end{array}$ & T Statistics \\
\hline $\begin{array}{l}\text { Communication Quality } \rightarrow \\
\text { Customer Loyalty }\end{array}$ & 0,211813 & 0,210842 & 0,040760 & 0,040760 & 5,196532 \\
$\begin{array}{l}\text { Communication Quality } \rightarrow \text { Trust } \\
\text { Shared Value Quality } \rightarrow\end{array}$ & 0,348519 & 0,350979 & 0,053652 & 0,053652 & 6,495946 \\
$\begin{array}{l}\text { Customer Loyalty } \\
\text { Shared Value Quality } \rightarrow \text { Trust }\end{array}$ & 0,385838 & 0,388697 & 0,044708 & 0,044708 & 8,630134 \\
Trust $\rightarrow$ Customer Loyalty & 0,230564 & 0,227732 & 0,051916 & 0,051916 & 4,441126 \\
\hline Source: Primary and & 0,4601 & 0,477892 & 0,029064 & 0,029064 & 16,466930 \\
\hline
\end{tabular}

Source: Primary analyzed data, 2017

\section{HYPOTHESIS TESTING AND DISCUSSION}

Based on the correlation test between constructs in Tables 4 and 5, the hypotheses proposed in this study can be explained as follows:

\section{a) Effect of Shared Value Quality on Customer Loyalty}

The first hypothesis proposed in this study is " The higher the shared value quality is, the more customer loyalty increases". In Table 4:13 shows that the relationship between shared value quality with customer loyalty has a significant positive effect because the value of $t$ statistic is greater than $t$ table ( $\mathrm{t}$ statistic 8.63>t table 1.66) at 5\% significance level. Thus, the first hypothesis proposed in this research is that the higher the shared value quality is, the more customer loyalty increases is accepted.

Values are the core idea that unites a community or organization. The quality of shared values among members of the organization minimizes the differences of interests between them and enhances the sense of interdependence with each other. Shared values are ideas, beliefs, and meanings accepted and adopted by an organization. The value conformity between individuals and their organizations will result in a positive outcome (Edwards and Cable, 2009). Customers and organizations of the same value tend to develop lasting relationships. The quality of shared values and beliefs provides a harmony of interests that eliminates the possibility of opportunistic behavior. Customers and managers share values that support their relational stability. The result of a quality shared value is the emergence of loyalty built on mutual interests. The quality of shared values between customers and managers also has the potential to affect intention in behaving (Zhang et al., 2014). Customers legitimize the existence of an event within the market. By integrating value conformity, it will help customers in strengthening the reasons for existence and loyalty. Customer accepts and approves existing goals and provides full support to the organization. Furthermore, customers who are emotionally tied to an organization are likely to re-transact and spread positive word-of-mouth words.

\section{b) The effect of Shared Value Quality on Trust}

The seco $\mathrm{n} d$ hypothe $\mathrm{s}$ is proposed in this research is "the higher the shared value quality i s, the more the trust increases". Based on Table 4:13 shows that the relationship between shared value quality with trust is a significant positive effect because the value of $\mathrm{t}$ statistic is greater than $t$ table ( $\mathrm{t}$ statistic $4.44>\mathrm{t}$ table 1.66 ) at $5 \%$ significance level. Thus, 
the second hypothesis which states "the higher the shared value quality is, the more the trust increases" is accepted.

Porter and Kramer (2011) underscores that the creation of quality shared values requires multiple actions, such as conceptualizing products and markets, redefining productivity and enabling the development of local clusters so as to focus on creating strong inter-organizational relationships. Shared values are able to resolve the polarization between profi t-taking and corporate social responsibility (Porter and Kramer, 2011). Organizations must therefore focus on quality shared values, whic h include economic and community values, or improv e the economic and social conditions of the communities in which they operate. Shared values are seen as one of the main predictors of trust. Shared values help and encourage trust and create a tendency for mutual trust (Brashear et al., 2003). Trust is very important to maintain and express the shared value created in the relationship of trust value. Shared values help to experience the highest trust and without any requirement (Mosavi and Ghaedi, 2012).

\section{c) Effect of Trust on Customer Loyalty}

The third hypothesis proposed in this study is " The higher the trust is, the more the customer loyality increases". Based on the results of path coefficient analysis in Table 4.13 shows that the relationship between trust with customer loyality is a significant positive effect because the value of $t$ statist ic is greater than t table ( $t$ statistic 16.47> t table 1.66) at 5\% significance level. Thus, the third hypothesis in this study which states "The higher the trust is, the more the customer loyality increases " is also accepted.

According to the theory of tru st, trust is a level of confidence in the reliability and integrity of partners who become partners in exchange. Pavlou and Fygenson (2006) expand this definition by conceptualizing trust as the extent to which customers believe that the company is performing well, ethically, legally and responsibly. Some experts suggest that feeling of trust leads to a positive impression of a company (Gefen et al., 2000; Pavlou and Fygenson, 2006). Customers feel confident about the quality of a product or service when they trust the company and believe that a reliable company applies greater ethical and social responsibility. Such beliefs make customers buy back and reuse services or products from companies they trust. Trust can lead to lo $\mathrm{n}$ g-term loyalty and strengthen the relationship between the two variables (Singh and Sirdeshmukh, 2000). Trust leads to customer loyalty because trust creates a high value exchange relationship. One important consequence of trust is a lasting relationship (Flavian et al., 2006).

\section{d) Influence of Communication Quality to Trust}

The fourth hypothesis proposed in this study is "The better communication quality is, the more the trust increases". Based on the results of path coefficient analysis in Table 4:13 shows that the relationship between communication quality with trust has a significant positive effect because the value of $t$ statistic is greater than $t$ table ( $\mathrm{t}$ statistic $6.49>\mathrm{t}$ table 1.66) at 5\% significance level. Thus, the fourth hypothesis in this study which states "The better communication quality is, the more the trust increases" is also accepted. 
Communication is an important segment of the entire business process. Communication behavior is related to sharing and exchanging information to improve organizational effectiveness (Tzafrir et al., 2004). The effectiveness of communication in the form of a meaningful and informal sharing of information both formal and informal between service providers and customers who have a sufficient level of sympathy with each other. Bennett and Barkensjo (2004) suggest that the quality of two-way communication should be increased frequently to encourage customer trust. Targeted communication also facilitates problem solving among the various parties, thereby increasing the likelihood of meeting the desired results by the customer. Yamaguchi (2009) views that communication can help transfer knowledge between parties. Effective communication leads to the development of trust and exchange of information needed, and creates trust in return.

\section{e) Influence of Communication Quality to Customer Loyalty}

The fifth hypothesis proposed in this research is " The better communication quality is, the more customer loyality increases ". Based on the results of path coefficient analysis in Table 4:13 shows that the relationship between communication quality with customer loyality has a significant positive effect because the value of $t$ statistic is greater than $t$ table ( $t$ statistic 5.19> t table 1.66) at 5\% significance level. Thus, the fifth hypothesis in this study that states "The better communication quality is, the more customer loyality increases" is also accepted.

Communication is a social deed for transmitting a message to others and creating an understanding with an eloquent style. Communication aims to expose the customer to the brand, where the effect can be maximized in terms of higher awareness and memory, so that the customer will buy the brand with the highest memory; and to satisfy the customer to the optimum level. Quality brand communication is a key integral element in managing brand relationships with customers, employees, suppliers, media, government regulators, and the public. Quality brand communication aims to increase customer loyalty to the brand by making customers more attached to the brand and strengthening their relationship with the brand over time (Zehir et al., 2011). The results of this study prove that communication quality has a significant effect on customer loyality. These findings are supported by some previous researches (such as Grace and O'Cass, 2005; Low and Lamb, 2000; Musriha, 2012) that prove that communication quality has a significant positive effect on customer loyality.

\section{CONCLUSION}

This research can generally be concluded that customer loyalty and trust in Syari'ah BNI of Semarang Branch, Syariah Mandiri Bank of Semarang Branch, Syariah BRI of Semarang Branch can be strengthened and enhanced through shared value quality, and communication quality. Based on the hypothesis testing proposed by using Structural Equation Modeling (SEM) on the basis of SmartPLS 3 software, it can be concluded as follows:

1. Shared value quality can significantly increase customer loyalty in Syari'ah BNI of Semarang Branch. This means that to improve customer loyalty, Syari'ah BNI of Semarang Branch needs to encourage shared value quality. 
2. Shared value quality can significantly increase trust in Syari'ah BNI Bank of Semarang Branch. It means that trust in Syari'ah BNI of Semarang Branch can be improved and strengthened through shared value quality.

3. Trust can increase customer loyality significantly in Syari'ah BNI of Semarang Branch. This means that trust becomes one of the main factors to encourage increased customer loyality.

4. Communication quality can significantly increase trust in Syari'ah BNI of Semarang Branch, Syariah Mandiri Bank of Semarang Branch, Syari'ah BRI Semarang. It means that the implementation of targeted and quality communication in Syari'ah BNI of Semarang Branch, Syariah Mandiri Bank of Semarang Branch, Syariah BRI of Semarang Branch is able to encourage the increase trust.

5. Communication quality can increase customer loyality significantly in Syari'ah BNI of Semarang Branch, Syariah Mandiri Bank of Semarang Branch, Syariah BRI Semarang. It means that to improve customer loyality in Syari'ah BNI of Semarang Branch, Syariah Mandiri Bank of Semarang Branch, Syariah BRI of Semarang Branch should instill and uphold communication quality.

\section{MANAGERIAL IMPLICATIONS}

The results of this study have implications on managerial policy as follows:

1. With regard to shared value quality variable, the organization must ensure security in every transaction so as to create confidentiality and calmness in the minds of customers.

2. With regard to communication quality variable, organizations should facilitate the attitude of speed of response so as to know and handle every customer's complaints and desires.

3. Related to variable trust, organization must improve reputation and perceived risk in order to make it more interesting and encourage customers to do transaction in Syari'ah BNI of Semarang Branch, Syariah Mandiri Bank of Semarang Branch, and Syariah BRI of Semarang Branch.

4. Related to customer loyalty variable, organization should encourage in facilitating good services so that customers can do repeat purchases.

\section{LIMITATIONS OF RESEARCH}

There are several things to note regarding the limitations in this study, including (1) all construct variables used in this study are measured only on the responses of the same respondents, where such measurement practices have the potential to cause bias. (2) The number of samples of this study is too little that only involves 100 respondents so that research results are difficult to generalize. Future research needs to be developed in a wider scope by comparing existing customer loyalty to domestic banks and private banks, and taking into account for demographic factors (such as education, age, gender, income, etc.) and adding other variables which are expected to increase customer loyalty, such as customer motives, value perception, brand engagement and social commerce. 


\section{REFERENCE}

Akmal1, P. Z. (2014). A Comparative Analysis of Customers' Satisfaction for Conventional and Islamic Insurance Companies in Pakistan. International Journal of Economics and Finance Vol. 6, No. 4.

Alfian Tan1, P. S. (2014). Pengembangan Dimensi Kualitas Layanan e-banking dan Hubungannya dengan Kepuasan dan Loyalitas Konsumen. Jurnal Ilmiah Teknik Industri, Vol. 13, No. 1.

Antioco, M., Moenaert, R., Feinberg, R., \& Wetzels, M. (2008). Integrating service and design: The influences of organizational and communication factors on relative product and service characteristics. Journal of the Academy of Marketing Science, 36, 501-521.

Arnold, S., R. V. Kozinets, and J. M. Handelman. 2001. "Hometown Ideology and Retailer Legitimation: The Institutional Semiotics of Wal-Mart Flyers." Journal of Retailing $77: 243-71$.

Awan, S., \& Cheng, Y. (2016). Improve Communication Quality by Understanding Customer Switching Behavior in China's Telecom Sector. iBusiness, 8, 70-83.

Ball D, Coelho PS, Machas A (2004). The role of communication and trust in explaining customer loyalty an extension to the European Customer Satisfaction Index (ECSI) model, Eur. J. Market. 38(9/10): 1272-1293.

Beckinsale, M. and Ram, M. (2006), "ICT adoption and e-business development: a framework for ethnic minority businesses", Proceedings of the 29th Conference on Institute for Small Business and Entrepreneurship (ISBE), Cardiff-Caerdydd, Wales, UK.

Bennett, R. and Barkensjo, A. (2004), "Relationship quality, relationship marketing, and client perceptions of the levels of service quality of charitable organisations", International Journal of Service Industry Management, Vol. 16 No. 1, pp. 81-106.

Beugelsdijk, S. \& Klasing, M. J. (2016). Diversity and trust: the role of shared values. Journal of Comparative Economics. Volume 44, Issue 3, Pages 522-540.

Boies, K., Fiset, J., \& Gill, H. (2015). Communication and trust are key: Unlocking the relationship between leadership and team performance and creativity. The Leadership Quarterly xxx (Article in press) xxx-xxx.

Born, M.J., Akkerman, A., Torenvlied, R., 2013a. Trust your boss or listen to the union? Information, social identification, trust, and strike participation. Mobilization Int. J. 18 (2), 161-178.

Brashear GT, Boles SJ, Bellenger ND, Brooks MCh (2003). “An empirical test of trust-building processes and outcomes in sales manager-salesperson relationship", J. Acad. Market. Sci. 31(2):189-200.

Bulchand, J., Melián, S. and González, B. (2011), "Improving hotel ratings by offering free WiFi”, Journal of Hospitality and Tourism Technology, Vol. 2 No. 3, pp. 235-246. 
Chaney, D. dan Martin, D. (2016). The Role of Shared Values in Understanding Loyalty over Time: A Longitudinal Study on Music Festivals. Journal of Travel Research, 1-14.

Chathoth, P.K. (2007), “The impact of information technology on hotel operations, service management and transaction costs: a conceptual framework for full-service hotel firms", Hospitality Management, Vol. 26 No. 2, pp. 395-408.

Christy Cussoy, I. P. (t.thn.). Analisis Pengaruh Accessibility dan Security terhadap Customer Satisfaction dan Customer Loyalty Nasabah KlikBCA.

Chu, S.-Y., \& Fang, W.-C. (2006). Exploring the relationships of trust and commitment in supply chain management. Journal of American Academy of Business, 9, 224-228.

Consumer perceptions of Internet banking in Finland: The moderating role of familiarity. (2008)). Journal of Retailing and Consumer Services 15, 266-276.

DiPietro, R.B. and Wang, Y. (2010), "Key issues for ICT applications: impacts and implications for hospitality operations", Worldwide Hospitality and Tourism, Vol. 2 No. 1, pp. 49-67.

Doney, P. M., \& Cannon, J. P. (1997). An examination of the nature of trust in buyer-seller relationships. Journal of Marketing, 61, 35-51.

Dimitriadis, S., Kouremenos, A. and Kyrezis, N. (2011), “Trust-based segmentation preliminary evidence from technology-enabled bank channels", International Journal of Bank Marketing, Vol. 29 No. 1, pp. 5-31.

Edwards, J. R., and D. M. Cable. 2009. "The Value of Value Congruence.” Journal of Applied Psychology 94 (3): 654.

Flavian, C., Guinaliu, M., \& Gurrea, R. (2006). The Role Played by Perceived Usability, Satisfaction and Consumer Trust on Website Loyalty. Information and Management 43, pp. 1-14.

Garau, J.B. and Orfila, S.F. (2008), "Internet innovation for external relations in the balearic hotel industry", Journal of Business \& Industrial Marketing, Vol. 23 No. 1, pp. 70-80.

Gefen, D., Straub, D., \& Boudreau, M. C. (2000). Structural equation modeling and regression: Guidelines for research practice. Communications of the Association for Information Systems, 4(1), 7.

Gillespie, N. A. \& Mann, L. (2004). Transformational leadership and shared values: the building blocks of trust. Journal of Managerial Psychology, Vol. 19 Iss: 6 pp. 588 - 607.

Grace, Debra and O'Cass, Aron (2005), "Examining the effects of service brand communications on brand evaluation", The Journal of Product and Brand Management. Santa Barbara. Vol. 14, Iss. 2/3; 106-117.

Greenwood, R., Raynard, M., Kodeih, F., Micelotta, E. R., \& Lounsbury, M. (2011). Institutional Complexity and Organizational Responses. The Academy of Management Annals, 5(1): 317-371.

Gustafsson, A., Roos, I. and Edvardsson, B. (2004) Customer Clubs in a Relationship 
Perspective: A Telecom Case. Managing Service Quality, 14, 157-168.

Ham, S., Kim, W.G. and Jeong, S. (2005), "Effect of information technology on performance in upscale hotels", International Journal of Hospitality Management, Vol. 24 No. 2, pp. 281-294.

Haneen A. Abu-Assi1, H. H.-D.-Z. (2014). Determinants of Internet Banking Adoption in Jordan. International Journal of Business and Management; Vol. 9, No. 12 .

Heinonen, K. (2007). Conceptualising online banking service value. JOURNAL OF FINANCIAL SERVICES MARKETING , 39-52.

Hojjati, S. N. ( 2013). Effects of Iranian online behavior on the acceptance of internet banking. JOURNAL OF ASIA BUSINESS STUDIES VOL. 7 NO. 2, 123-139.

Iqbal, Z. and Mirakhor, A. (2007), An Introduction to Islamic Finance, Theory and Practice, John Willey \& Sons (Asia) Pte Ltd, Singapore, pp. 126.

Jones, G.R. and George, J.M. (1998), "The experience and evolution of trust: implications for cooperation and teamwork", Academy of Management Review, Vol. 23 No. 3, pp. 53146.

Kayed, R.N. and Hassan, M.K. (2011), "The global financial crisis and Islamic finance", Thunderbird International Business Review, Vol. 3, pp. 551-64.

Keh, H. T. \& Xie, Y. (2009). "Corporate reputation and customer behavioral intentions: The roles of trust, identification and commitment" Ind. Market. Manage. 38:732-742.

Kenter, J.O., O’Brien, L., Hockley, N., Ravenscroft, N., Fazey, I., Irvine, K.N., Reed, M.S., Christie, M., Brady, E., Bryce, R., Church, A., Cooper, N., Davies, A., Evely, A., Everard, M., Fish, R., Fisher, J.A., Jobstvogt, N., Molloy, C., Orchard-Webb, J., Ranger, S., Ryan, M., Watson, V., Williams, S., 2015. What are shared and social values of ecosystems? Ecol. Econ. 111, 86-99.

Landry, T. D., T. J. Arnold, and J. B. Stark. 2005. "Retailer Community Embeddedness and Consumer Patronage.” Journal of Retailing and Consumer Services 12:65-72.

Maharsi, S. F. (MEI 2006). Analisa Faktor-Faktor yang Mempengaruhi Kepercayaan dan Pengaruh Kepercayaan Terhadap Loyalitas Pengguna Internet Banking di Surabaya. Jurnal Akuntansi dan Keuangan, Vol. 8, No. 1, 35-50.

Minghetti, V.(2003), "Building customer value in the hospitality industry: towards the definition of a customer-centric information system”, Information Technology and Tourism, Vol. 6, No. 2, pp. 141-152.

Mosavi, S. A. \& Ghaedi, M. (2012). A survey on the relationship between trust, customer loyalty, commitment and repurchase intention. African Journal of Business Management Vol. 6(36), pp. 10089-10098. 
Musriha. (2012). EFFECT OF SERVICESCAPE AND EMPLOYEE COMMUNICATION QUALITY ON CUSTOMER LOYALTY OF MANDIRI BANK IN SURABAYA. Academic Research International, Vol. 2, No. 1.

P.K. Gupta, J. M. (2008). INTERNET BANKING IN INDIA - CONSUMER CONCERNS AND BANK STRATEGIES. GLOBAL JOURNAL OF BUSINESS RESEARCH, Vol. 2, No 1.

Panda, Tapan K. (2004) "Consumer Response to Brand Placements in Films Role of Brand Congruity and Modality of Presentation in Bringing Attitudinal Change Among Consumers with Special Reference to Brand Placements in Hindi Films" South Asian Journal of Management. New Delhi: Oct-Dec 2004. Vol. 11, Iss. 4; pg. 7, 19 pgs.

Park, J. G., Lee, S., \& Lee, J. (2014). Communication effectiveness on IT service relationship quality. Industrial Management \& Data Systems. Vol. 114 No. 2, pp. 321-336.

Pavlou, P. A., \& Fygenson, M. (2006). Understanding and predicting electronic commerce adoption: An extension of the theory of planned behavior. MIS Quarterly, 30, 115-143.

Porter, M. E., \& Kramer, M. R. (2011). The big idea: Creating shared value. Harvard Business Review, 89(1), 2.

Raciti, M. and Dagger, T. (2010) Embedding Relationship Cues in Written Communication. Journal of Services Marketing, 24, 103-111.

Rasheed, F. A. \& Abadi, M. F. (2014). Impact of service quality, trust and perceived value on customer loyalty in Malaysia services industries. Procedia - Social and Behavioral Sciences $164 ; 298-304$.

Reichheld, F. F., \& Schefter, P. (2000). E-loyalty: Your secret weapon on the web. Harvard Business Review, 78(4), 105-113.

Richard, M. A. (2014, 7-10 July, Bournemouth, UK). Digital banking: Investigating the use of social media and mobile applications in building relationships, loyalty and reducing churn. Academy of Marketing Conference.

Sauer, J.B. (2002), "Metaphysics and economy - the problem of interest", I n t e r n a t i o n a 1 Journal of Social Economics, Vol. 29 Nos 1/2, pp. 97-118.

Service, R.W. (2005), "CQ: the communication quotient for IS professionals", Journal of Information Science, Vol. 31 No. 2, pp. 99-113.

Sigala, M. and Connolly, D. (2004), "In search of the next big thing: IT issues and trends facing the hospitality industry - a review of the sixth annual pan-european hospitality technology exhibition and conference (EURHOTEC 2001)", Tourism Management, Vol. 25 No. 6, pp. 807-809.

Singh, J., \& Sirdeshmukh, D. (2000). Agency and trust mechanisms in consumer satisfaction and loyalty judgments. Journal of the Academy of Marketing Science, 28(1), 150-167. 
Sun, C.B., Wilcox, R. and Zhu, T. (2008) Ignoring Your Best Customer? An Investigation of Customer Satisfaction, Customer Retention and Their Financial Impact. Journal of Relationship Marketing, 6, 87-116.

Thornton, P. H., Ocasio, W., \& Lounsbury, M. (2012). The institutional logics perspective. John Wiley \& Sons, Inc.

Yamaguchi, I. (2009). Influences of organizational communication tactics on trust with procedural justice effects: A cross-cultural study between Japanese and American workers. International Journal of Intercultural Relations, 33(1), 21-31.

Yoana Arina Pramudita dan Edwin Japarianto, S. M. ((2013)). Analisa Pengaruh Customer Value dan Customer Experience terhadap Customer Satisfaction di De Kasteel Resto Surabaya. Jurnal Manajemen Pemasaran Petra Vol. 1, No. 1, , 1-7.

Zehir, C., Sahin, A., Kitapçı, H., Özsahin, M. (2011). The Effects of Brand Communication and Service Quality In Building Brand Loyalty Through Brand Trust; The Empirical Research On Global Brands. Procedia Social and Behavioral Sciences 24; 1218-1231.

Zhang, H., X. Fu, L. A. Cai, and L. Lu. 2014. "Destination Image and Tourist Loyalty: A MetaAnalysis." Tourism Management 40:213-23.

Zhou, Z., Zhang, Q., Su, C., \& Zhou, N. (2011). How do brand communities generate brand relationships? Intermediate mechanisms. Journal of Business Research. 